Abstracta Iranica Abstracta Iranica

Revue bibliographique pour le domaine irano-aryen

Volume 42-43 | 2021

Comptes rendus des publications de 2019-2020

\title{
Mauro Serena. "Metastasio and the Persian King. Exemplarity and Senecan Echoes in the Artaserse and the Temistocle"
}

Reinhardt Pirngruber

\section{(2) OpenEdition Journals}

Electronic version

URL: https://journals.openedition.org/abstractairanica/53479

DOI: 10.4000/abstractairanica.53479

ISSN: 1961-960X

Publisher:

CNRS (UMR 7528 Mondes iraniens et indiens), Éditions de l'IFRI

\section{Electronic reference}

Reinhardt Pirngruber, "Mauro Serena. "Metastasio and the Persian King. Exemplarity and Senecan Echoes in the Artaserse and the Temistocle'"', Abstracta Iranica [Online], Volume 42-43 | 2021,

document 57, Online since 30 December 2021, connection on 28 December 2022. URL: http:// journals.openedition.org/abstractairanica/53479; DOI: https://doi.org/10.4000/abstractairanica. 53479

This text was automatically generated on 28 December 2022.

All rights reserved 


\title{
Mauro Serena. "Metastasio and the Persian King. Exemplarity and Senecan Echoes in the Artaserse and the Temistocle"
}

\author{
Reinhardt Pirngruber
}

\section{REFERENCES}

Mauro Serena. "Metastasio and the Persian King. Exemplarity and Senecan Echoes in the Artaserse and the Temistocle" in R. Rollinger, K. Ruffing, L. Thomas (eds.). Das Weltreich der Perser. Rezeption - Aneignung - Verargumentierung. Wiesbaden: Harrassowitz Verlag, 2019, p. 215-238.

M. Serena analyses two works of $18^{\text {th }}$ century librettist Pietro Metastasio. The A. shows that the storylines, while based on historical accounts, are decisively shaped by Metastasio's conception of ideal kingship, influenced in its turn by Seneca's key virtues of a model ruler such as clemency and dignity.

\section{AUTHORS}

REINHARDT PIRNGRUBER

Institut für Orientalistik, Wien 